\title{
Como caçar (e ser caçado por) imagens: Entrevista com W. J. T. Mitchell
}

\author{
Daniel B. Portugal e Rose de Melo Rocha
}

\section{Daniel B. Portugal | daniel@espelhodetinta.com.br}

Mestrando em Comunicação e Práticas de Consumo pela ESPM-SP. Bolsista FAPESP.

\section{Rose de Melo Rocha | rrocha@espm.br}

Doutora em Ciências da Comunicação pela ECA/USP com pósdoutorado em Ciências Sociais/Antropologia na PUC-SP. É Coordenadora Adjunta do Programa de Mestrado em Comunicação e Práticas de Consumo da ESPM-SP, onde também atua como professora e pesquisadora.
W. J. T. Mitchell, professor de História da Arte e de Inglês na Universidade de Chicago, é editor do periódico Critical Inquiry e autor de diversos livros e artigos. Focando seus estudos na problematização da interface entre visão e linguagem nas artes plásticas, na literatura e na mídia, Mitchell propõe métodos bastante originais de se abordar as imagens, construindo novas perspectivas para o que ele denomina, seguindo Panofsky, uma Iconologia. Em suas reflexões, cunhou a difundida expressão "virada imagética" (pictorial turn). 0 que justifica a noção de uma "virada", diz o autor,

[...] não é o fato de termos um poderoso modelo das representações visuais que estaria ditando os termos da teoria cultural, mas sim que as imagens constituem um ponto de peculiar fricção e desconforto junto a uma larga faixa de questionamentos intelectuais. A imagem agora goza de um status localizado em algum ponto entre aquilo que Thomas Khun chamou de "paradigma" e uma anomalia, emergindo como um tópico central de discussão nas ciências humanas do mesmo modo que a língua o fez: ou seja, como um tipo de modelo ou figura para outras coisas [...], e como um problema não solucionado, talvez até mesmo como objeto de sua própria "ciência", aquilo que Panofsky chamou de "Iconologia" (MITCHELL, 1994, p. 13, tradução nossa). 
Ao longo da entrevista que segue, Mitchell fala mais detalhadamente sobre os fundamentos e métodos de sua iconologia crítica e comenta, à sua luz, temas bastante relevantes para as cenas intelectual e midiática contemporâneas. Acreditamos que suas respostas também evidenciam a importância dos estudos por ele desenvolvidos para o debate no campo da Comunicação, iniciativa que se justifica especialmente por estes serem ainda pouco difundidos no Brasil. Como ele próprio nota, seria impossível abordar a mídia sem se referir às imagens que nela transitam e aos regimes de visibilidade que elas engendram. "Como 0 Deus do Monoteísmo, como a 'Matrix' da ficção científica moderna, a mídia está em todos os lugares e em nenhum lugar" (2005, p. 216). Ela "não se localiza em um espaço ou coisa particular, mas é, ela própria, o espaço no qual mensagens e representações circulam e prosperam" (p. 216).

Professor Mitchell, foi uma honra tê-lo em nosso país por ocasião do simpósio "Crise da imagem ou crise das teorias?", realizado no Goethe Institut da cidade de São Paulo, no ano de 2008. Nesse simpósio, durante a abertura de sua inspiradora fala, você disse algo intrigante: "a crise da imagem $e ́$ a crise da teoria". 0 senhor poderia desenvolver este pensamento para nós? Além disso - e já estaríamos, na verdade, fazendo uma segunda pergunta -, você passou tempo suficiente aqui no Brasil para fazer alguns comentários sobre o país? Estávamos pensando em algo como "comentários de um iconologista"...
Não quero exagerar ou acentuar a linguagem da crise. Afinal, na perspectiva da crítica, o principal ponto é exatamente desencadear uma crise. É um cliché de nosso tempo - talvez de todos os tempos - considerar que "o problema é a imagem" - a falsa imagem, a dissimuladora, a ilusória percepção, o artifício superficial, o simulacro e o espetáculo, a propaganda, a publicidade, a embalagem, e (a mais traiçoeira de todas) a ideologia, que é literalmente a "idolatria das ideias". Então o que é a imagem, esta que pode ter todos estes efeitos? Que teoria seria adequada para domar a imagem, desmistificá-la, explicá-la ou destruí-la?

E se a resposta para isso é que nenhuma teoria é ou pode ser adequada à imagem, que o próprio conceito desafia todas as ferramentas da reflexão teórica? E se a imagem fosse o "signo selvagem" que escapa a todas as definições, sistemas e mídias? Isso certamente seria uma crise para a teoria, pelo menos para o tipo de teoria que tenta pacificar ou conter a imagem. E há muitas evidências de que esse foi o papel por ela desempenhado na filosofia durante longo tempo, quando a retórica do iconoclasmo reinava. Desde a tentativa de Platão de banir as imagens (através de uma imagem ampliada, na alegoria da caverna), houve um embate entre logos ( razão) $e$ imaginário. Os valores permeando esse embate foram decisivamente revertidos por Nietzsche em 0 crepúsculo dos ídolos, onde 0 caráter sensual, fantástico da imaginação é reafirmado, e a única "destruição de imagens" é a das tábuas da lei, enquanto os ídolos são meramente tocados com um martelo ou tuning fork (garfo de afinação). 
Esse é o método que adoto, uma nãoiconoclasta "reverberação dos ídolos" (sounding of the idols) como o espírito de uma iconologia crítica, ou de uma teoria das imagens que não sonha em dominar a imagem. O famoso comentário de Gilles Deleuze - o de que a filosofia é sempre uma forma de iconologia - ou a reclamação de Wittgenstein - a de que "uma imagem nos aprisionou" (isso é, a nós, filósofos) - são sintomas desse longo embate entre teoria e imagem. E sempre que a base técnica da produção e da circulação de imagens se transforma (i.e., a invenção da fotografia, cinema, televisão, a imagem digital, prensa mecânica), uma nova crise da imagem é declarada, e, com ela, uma nova crise da teoria. $A$ isso denomino versão perene ou recorrente da "virada imagética" (pictorial turn).

Como um iconologista, o Brasil me pareceu maravilhoso e extasiante, da beleza espetacular do Rio de Janeiro aos sublimes espraiamentos de São Paulo. E sei que só vi um fragmento mínimo deste fantástico país. Da próxima vez, vou querer ver a Amazônia, mas também as favelas, que são uma forma crucial dos "cenários sociais extremos" que estou estudando, um tópico que se estende dos guetos negros de Chicago à prisão a céu aberto conhecida como Gaza. Estou especialmente interessado no tipo de arte e imagem que as pessoas produzem em estado de falta e privação. Sabemos, é claro, que a maioria das belas artes é produto da luxúria e do excesso, mas existem formas que emergem do que poderíamos chamar "terrível necessidade" (dire straits). As fabulosas artes populares brasileiras envolvendo figuras de cerâmica da vida cotidiana me pareceram especialmente memoráveis. Esse gênero, creio, emergiu quando a indústria de cerâmica sofreu uma crise.

\section{Como a figura do "iconologista" já apareceu} na primeira pergunta, seria muito interessante escutar seus pensamentos sobre o trabalho do iconologista e suas especificidades.

Já respondi acima a essa pergunta, mas minha estratégia básica é trabalhar como um caçador-coletor de imagens através da mídia, livremente transgredindo fronteiras históricas e disciplinares entre, digamos, film studies e história da arte, ou entre a arte antiga, "primitiva", como é chamada, e a moderna. Não que eu ignore as fronteiras. Ao contrário: o momento do cruzamento de uma fronteira é parte crucial do trabalho: não apenas notar a fronteira, mas se perguntar de que tipo é e como foi instituída. Ela esteve sempre lá (e.g., a fronteira entre arte de elite e arte popular, ou entre imagens verbais e imagens visuais), ou foi uma invenção histórica específica de uma cultura ou civilização particular? Estou especialmente interessado na migração das imagens, seus cruzamentos (cross-breeding) e hibridações, características cruciais da evolução histórica das imagens em espaços imperiais e coloniais - e.g. América do Norte e Brasil. Os interessados nesse aspecto do meu trabalho deveriam ler meu artigo "Migrating images: totemism, fetishism, idolatry" (2004).

Quanto às noções teóricas que permeiam meus métodos iconológicos, ideias como a de "metapicture", a de "image/text", a da distinção entre image (imagem imaterial) $e$ 
picture (imagem material) e a da "biopicture", sugeriria que os interessados consultassem meu pequeno artigo "Four fundamental concepts of image science"(2008a).

Durante sua apresentação no simpósio "Crise da imagem ou crise das teorias?" chamou nossa atenção o senhor ter incorporado o termo "iconofagia", cunhado por Norval Baitello, um teórico da mídia brasileiro que produz reflexões bastante originais sobre a imagem - e esta incorporação você a fez de um modo muito interessante, mostrando imagens de algumas pinturas rupestres de Lascaux que representavam herbívoros (caça) e depois um frame do filme "Parque dos Dinossauros", no qual a imagem de um código genético é projetada em um "velociraptor" que caça seres humanos. Algo instigante sobre o termo "iconofagia" é sua ambiguidade - são homens que devoram imagens, imagens que devoram imagens, ou imagens que devoram homens? Você gostaria de fazer comentários relacionados à noção de "iconofagia"? Parecenos que ela se encaixa perfeitamente em todo este cenário da "imagem viva" que o senhor constrói no livro What do pictures want?

Sim, chamou-me atenção o conceito de Baitello, que é bastante ressonante com minha própria meta-imagem da imagem desejante, faminta e devoradora (ou devorada). Como vocês devem lembrar, abro What do pictures want? com a discussão de uma cena do filme de terror "Videodrome", de David Cronenberg, no qual o herói (James Woods) está a passos de afundar sua cabeça na boca da imagem televisionada de sua amante, Nicky Brand. A tela da televisão ganhou vida e se tornou uma boca lasciva, com lábios vermelhos e brilhantes dentes brancos, chamando o herói: "venha para Nicky". Quando me pedem uma resposta rápida para a pergunta “O que querem as imagens?", sempre respondo que elas querem ser beijadas. Mas então surge a questão: o que é um beijo? E a resposta é que ele é um gesto de incorporação, de vontade de engolir o outro sem matá-lo - de "comê-lo vivo", como se diz. Então queremos assimilar a imagem a nossos corpos, e elas querem assimilar-nos aos delas. É um caso amoroso correspondido, mas um caso permeado tanto por perigo, violência e agressão quanto por afeição.

Em seu livro What do pictures want?, é apresentada uma imagem bizantina de Cristo cuja face foi desfigurada até o limite do irreconhecimento pelos constantes beijos. Esse ícone, você escreve, "é uma imagem que quer o corpo, o sangue e o espírito do observador". Mas, considerando o resultado da realização dos desejos que você menciona, não poderíamos dizer que a imagem estava "viciada"? Ou, olhando o problema sob outra perspectiva, não é possível que a imagem não quisesse os beijos e que eles tenham sido infligidos a ela? Ou seja, não podemos considerar que a imagem foi abusada por seus observadores? Nesse caso, teríamos que lidar com a difícil questão de como os desejos dos humanos e os desejos das imagens se relacionam uns com os outros.

Não acho que a imagem tenha sido abusada nesse caso, ainda que tenha sido destruída. Toda a moldura litúrgica e ritual desse processo é de sacrifício, não de abuso. Os ícones oferecem seu "corpo" para o observador em analogia 
exata ao oferecimento do sangue e do corpo de Cristo no sacrifício da Missa, uma refeição ritual que se parece muito com canibalismo ou antropofagia - aquilo que podemos pensar como o análogo carnal e literal da iconofagia. Claramente, isso poderia ser visto como uma forma de abuso ou de mutilação por alguém fora do ritual - por um historiador da arte, por exemplo, que quer preservar o ícone da destruição. Para aqueles inseridos no ritual, entretanto, os beijos são viciantes dos dois lados - do lado do desejo do adorador e do da demanda do ícone.

0 diagrama reproduzido abaixo, apresentado em seu livro Iconology (1987), parecenos muito esclarecedor, assim como todo o capítulo "What is an image?" que o contém. 0 senhor poderia comentar um pouco sobre a miríade de sentidos do termo "imagem"? Para utilizar sua própria pergunta, "o que é uma imagem"?
Em What do pictures want?, por exemplo, você diferencia picture de image, tratando a primeira como "coisa" - um objeto ou um ser, um exemplar - e a segunda como uma entidade abstrata - como uma espécie. Em português, usamos o termo "imagem" tanto para picture quanto para image, então, aqui, essa diferenciação tão interessante que está sendo proposta não poderia ser simplesmente retirada da linguagem cotidiana. Desejaria dizer algo sobre isso?

Gostaria de reunir as duas questões modificando o diagrama acima de uma maneira bastante simples: desenhe duas ovais, uma à esquerda contendo o lado "gráfico/ ótico/perceptual" do diagrama, a outra, à direita, contendo o lado "perceptual/mental/ verbal". Você verá imediatamente que elas se interceptam no meio, onde a imagem perceptual se localiza. Agora, nomeie a oval da esquerda "pictures" e a da direita "images" e verá como o diagrama taxionômico da imagem é dividido 
entre o reino das imagens materiais - isto é, imagens que podem ser vistas em suportes materiais, que podem ser penduradas na parede, impressas numa página ou destruídas - $e$ as imagens imateriais que surgem na mente como fantasias, sonhos, memórias ou as imagens que surgem na mente de uma leitora enquanto ela lê um texto, visualizando personagens, cenas e ações ou percebendo as figuras (símiles, metáforas) que compõem 0 dominio das imagens verbais.

Agora, é claro que a oposição "material imaterial" é somente uma conveniência para nos ajudar a assimilar a distinção picture/ image. Os dois lados são, em última instância, "materiais", no sentido de que a imagem mental, por exemplo, precisa da mente-corpo do observador como suporte material; e a mais sólida imagem material - uma estátua de bronze - transmite uma imagem que pode ser copiada em outro meio, por exemplo, uma fotografia, uma descrição, uma memória.
Então, a distinção picture/image não está, em última instância, confinada em um lado do diagrama das imagens, mas está distribuída através dele. Sob meu ponto de vista, é parte da ontologia fundamental das imagens que elas sejam TANTO materiais quanto imateriais, tanto corporificadas em objetos e lugares particulares quanto migrando eternamente através das fronteiras e corpos da mídia. A maioria das línguas (alemão, português) faz com que isso pareça natural por ter, como você aponta, apenas uma palavra (bild; imagem) para os dois. O inglês é a única língua que eu conheço que encoraja uma distinção vernacular entre a imagem material (picture) e a imagem imaterial (image) - a picture é algo com uma moldura, que você pendura na parede; a image é alguma coisa que aparece em uma picture. É claro que mesmo esta distinção vernácula pode se dissipar na prática, mas é uma distinção que parece natural para o falante nativo da língua inglesa. 
A imbricação entre a imagem material e a imaterial é capturada mais vividamente na intercessão dos conjuntos que desenhamos acima, o reino da imagem perceptual - e, podemos argumentar, reino também de todo o conceito da imagem que ocupa a posição superior "pai" ou "raiz" no diagrama. A imagem perceptual está precisamente na fronteira entre as realidades material e mental. Ela é a interface entre mente e mundo, uma interface que se abre, entretanto, para as profundezas tanto da mente como do mundo.

Em seu livro Iconology, você escreve que "a história da cultura é em parte a história de uma prolongada luta por dominação entre signos linguísticos e imagéticos, cada um reivindicando para si certos direitos de propriedade sobre uma 'natureza' à qual somente ele teria acesso". Esse é um dos muitos pontos nos quais, acreditamos, seu trabalho se aproxima do de Vilém Flusser, filósofo tcheco-brasileiro.

Flusser (2002) também dá grande importância a essa luta que você menciona. Ele enxerga três diferentes momentos nessa briga. 0 primeiro é a pré-história, na qual a imagem reina sozinha. 0 segundo - história - começa com o advento da escrita e é marcado pelo embate entre imagem/imaginação e texto/ concepção. Quando a prensa é inventada, o texto começa a dominar a imagem, levando à textolatria. Mas, quando a textolatria atinge grau máximo, um terceiro ator - a imagem técnica - entra em cena, inaugurando um terceiro momento - a pós-história. Para Flusser, existe uma diferença radical entre imagem e imagem técnica: a primeira "imagina" o mundo enquanto a segunda "imagina" textos (textos científicos que programam o aparelho que a produz) que "concebem" imagens que "imaginam" o mundo.

Bem, é certamente difícil e impróprio resumir o complexo pensamento de Flusser em poucas linhas. 0 senhor conhece o trabalho que ele desenvolveu? Se sim, quais são suas impressões dele? Parece-lhe que esse embate entre texto e imagem pode ser subdivido em momentos similares aos propostos por Flusser?

Conheço o trabalho de Flusser apenas superficialmente, mas o que li me pareceu muito intrigante. Sua história de três fases do embate texto-imagem me faz lembrar de outros teóricos da mídia, especialmente da progressão em quatro fases de Marshall McLuhan - da era de oralidade à cultura do manuscrito à cultura da impressão à era eletrônica - ou a sucessão de "mediascapes" de Regis Debray. Devo admitir que sou um pouco cético em relação a essas grandes reduções da historia humana a essas narrativas esquemáticas. Um dos problemas é que elas podem levar a uma forma dedutiva de historicismo feita de cima para baixo, na qual, uma vez que a natureza essencial de uma era ou período foi definida, fica fácil chegar a uma fórmula para aquilo que deve ser verdade sobre todos os textos, imagens e obras de arte naquele periodo.

Meu método enfatiza, por um lado, a particularidade histórica de tempo e espaço, e, por outro, tenta descrever as características fenomenológicas e ontológicas subjacentes às palavras e às imagens que parecem permanecer através da história, permitindonos compreender pelo menos em parte coisas 
(como as pinturas rupestres de Lascaux) que estão inimaginavelmente distantes de nós. No que diz respeito à história, então, eu quero enfatizar o anacronismo, a tendência dos artifícios humanos de pular de seu "período" para o nosso ou para outros e nos mostrar como "o tempo está fora de eixo". Adoro o fenômeno do artista cujo trabalho simplesmente não se encaixa no "estilo do período" ou no modo dominante, mas que é regressivo ou orientado para o futuro, algumas vezes os dois ao mesmo tempo (para um ótimo exemplo disso, veja o recente trabalho de Georges Didi-Huberman sobre Fra Angelico). E gosto de ler a história das imagens de trás para frente, e este é o meu método em Iconology (1987), onde retrocedo de teóricos modernos como Nelson Goodman e Ernst Gombrich para figuras comparáveis no Iluminismo, Lessing e Burke. Ou, em um artigo mais recente sobre a representação da idolatria, retrocedo de Nietzsche para William Blake e para Poussin, para que possamos olhar para as pinturas de Poussin sobre a idolatria ( $O$ bezerro de ouro e A praga em Ashdad) com olhos condicionados por pensadores posteriores.

Ainda há muita discussão sobre a noção de "sociedade do espetáculo" ocorrendo no campo da Comunicação. Como você mesmo observa em What do pictures want?, a posição de Debord pode ser interpretada como sendo bastante iconoclasta e mostraria um desconforto com a imagem que pode ser sentido - novamente, como você observa - em diversas disciplinas em nossa era. Esse desconforto, parece, foi o que o levou a cunhar a expressão "virada imagética" (pictorial turn). 0 senhor poderia comentar um pouco sobre a virada imagética e sobre a noção debordiana de uma "sociedade do espetáculo"?

Penso que Debord nos ofereceu uma intervenção crucial para a crítica da imagem, mas duvido de sua adequação ao nosso momento atual. 0 iconoclasmo é muito maniqueista e muito preso a um ódio da cultura de massa e da mídia, vistas como meros instrumentos do capital. Acho que estamos agora em um novo regime midiático que está oferecendo experiências sociais e psicológicas diferentes - dentre as mais dramáticas, a emergência do que Lev Manovich denomina "mídia social" (YouTube, a internet de modo geral), que torna novos movimentos sociais possiveis. A eleição de Obama é em parte um produto desta revolução. Se quiserem uma crítica mais desenvolvida de Debord como guia para a crítica em nosso tempo, sugiro que vejam meu artigo "The Spectacle Today" (2008b).

Você provavelmente já respondeu a centenas de perguntas similares, mas gostaríamos muito de escutar algumas reflexões iconológicas relacionadas à eleição de Barack Obama.

Obama é não somente o primeiro presidente negro, mas o primeiro presidente conectado (wired). Ele entende, como raramente se fez antes na política americana, que o poder político pode ser mobilizado através de redes e movimentos sociais. Também possui uma compreensão precisa da importância de sua própria imagem - isto é, de sua imagem corporal, física, e dos inúmeros códigos 
culturais que a cercam. Dizer que ele é negro claramente não é suficiente. Ele é um mulato, um híbrido, mestiço, e misturado em todos os sentidos. Ele seria um presidente perfeito para o Brasil, obviamente! De fato, ele seria um ótimo líder para qualquer democracia moderna que tenta superar sua negra história de escravidão, guerra civil e racismo. Não é um acidente que Obama seja um ícone global de esperança e mudança, e que tal fato tenha sido capturado graficamente por inúmeros artistas, mais notavelmente por Shepard Fairey, cujos pôsteres de Obama sem dúvida aparecerão nos selos americanos um dia.

Mas, além da fabulosa adequação de sua imagem ao momento atual, há o entendimento do próprio Obama de seu papel como ícone. Ele refletiu brilhantemente sobre esse papel, observando que sua imagem faz dele um objeto para as esperanças projetadas de vastas multidões. Ao invés explorar esse fato, sua tendência é espelhar essas esperanças de volta para a multidão, insistindo que "o importante não sou eu. São vocês. Nós somos aquele que estávamos esperando". 
Reprodução da entrevista na língua original How to hunt (and be hunted by) images: an interview with W. J. T. Mitchell

\section{By Ms. Daniel Portugal \\ \& Profa. Dra. Rose de Melo Rocha}

We would like to begin this interview saying that it was an honor having you here visiting our country in the occasion of the congress Image crisis or theory crisis? last year. Your speech during this congress was very inspiring. In its opening you played with the title and said something we found very interesting: "the crisis of image is the crisis of theory". Could you expand that thought for us? Also and that would actually be already a second question - have you spent time enough here in Brazil to make some comments about our country? We were thinking of something like "the impressions of an iconologist"...

I do not want to overdo the language of crisis. After all, from the standpoint of criticism, the whole point is to bring things to a crisis. It is a cliché of our time - perhaps of every time - that "the problem is the image" - the false image, the deceptive, illusory perception, the superficial artifice, the simulacrum and the spectacle, propaganda, advertizing, packaging, and (most insidious of all) ideology, which is literally the "idolatry of ideas." So what is the image that it can have all these effects? What theory would be adequate to tame the image, demystify it, explain it, or destroy it?

What if the answer to this is that no theory is or can be adequate to the image, that the very concept defies all the tools of theoretical reflection? What if the image were the "wild sign" that escapes all the definitions and systems and media? That would surely be a crisis for theory, at least the kind of theory that seeks to pacify or contain the image. And there is plenty of evidence that this is the role it has played in philosophy for a very long time, where the rhetoric of iconoclasm has ruled. Ever since Plato's attempt to banish images (by means of an extended image in the allegory of the cave), there has been a struggle between logos (reason) and the imaginary. The values underlying this struggle were decisively reversed by Nietzsche in Twilight of the Idols, where the sensuous, fantastic character of imagination is reaffirmed, and the only imagesmashing is of the tablets of the law, while the idols are merely "touched" with a hammer or tuning fork.

This is the method I embrace, a noniconoclastic "sounding of the idols" as the spirit of a critical iconology, or a theory of images that does not dream of mastering the image. Gilles Deleuze's famous remark that philosophy is always a form of iconology, or Wittgenstein's complaint that "a picture held us captive" (us philosophers, that is) are symptoms of this long struggle between theory and the image. And every time the technical basis of image production and circulation changes (i.e., the invention of photography, cinema, television, the digital image, reproductive print-making, of metal casting and stamping) a new crisis of the image is declared, and along with it a new crisis of theory. This is what I call the perennial or recurrent version of "the pictorial turn". 
As an iconologist, Ifound Brazil wonderful and overwhelming, from the spectacular beauty of Rio to the sublime sprawl of São Paulo. And I know that I have only seen a tiny fragment of this marvelous country. I know that next time I will want to see the Amazon, but also the favelas, which are a crucial form of the "extreme social landscapes" that I am studying, a topic that extends from the Black ghettos of Chicago to the open-air prison known as Gaza. I am especially interested in the kind of art and images that people produce in a state of deprivation and lack. Of course we know that most fine art is a product of luxury and surplus, but there are forms that arise out of what might be called "dire straits". I found the fabulous popular arts of Brazil, involving ceramic figures of everyday life, especially memorable. This genre, I take $i t$, emerged when the ceramics and pottery industry underwent a crisis.

Since the figure of the "iconologist" already appeared in the first question, we thought it would be very interesting to hear your thoughts about the iconologist's work and its specificities.

I have already answered this above, but my basic strategy is to work as a huntergatherer of images across the media, freely transgressing historical and disciplinary borders between, say, film studies and art history, or ancient and so-called "primitive" and modern art. It is not that I ignore the borders. On the contrary: the moment of crossing a border is a crucial part of the work - not only noticing the border, but asking what kind it is and how it came to be. Was it always there (e.g., the boundary between elite and popular art, or between verbal and visual images), or was it a specific historical invention of a particular culture or civilization? I am interested especially in the migration of images, their cross-breeding and hybridity, crucialfeatures of the historical evolution of images in imperial and colonial spaces - e.g. North America and Brazil. Anyone interested in this aspect of my work might check the article entitled "Migrating Images: Totemism, Fetishism, Idolatry" (2004). As for the theoretical notions that underlie my iconological methods, ideas such as the "metapicture," the "image/text," the "image/ picture" distinction, and the "biopicture", I would suggest that they read my short essay "Four fundamental concepts of image science" (2008a).

If you do not mind, we would like to make one more question related to the congress we mentioned in the first question. One thing that drawned our attention in your speech is that you incorporated - in a very interesting way, showing the picture of some lascaux drawing of herbivores (game) and then a frame of the Jurassic Park movie in which a genetic code is projected on a velociraptor hunting human beings - you incorporated in your speech, we were saying, the term "iconophagy" (iconofagia), coined by Norval Baitello, a Brazilian media theorist that produces very original reflections about the image. One very interesting thing about the term "iconophagy" is its ambiguity - is it men that devour images, images that devour images, or images that devour men? Would you like to 
make some comments related to the notion of "iconophagy"? It seems to us that it fits perfectly this whole "living image" scenario you build in What do pictures want?

Yes, I was very struck by Baitello's concept, which is very resonant with my own metapicture of the desiring, hungry, and devouring (or devoured) image. As you may recall, I open What do pictures want? with a discussion of a scene from David Cronenberg's horror film, Videodrome, in which the hero (James Woods) is about to plunge his head into the mouth of the televised image of his lover, Nicky Brand. The television screen has come alive and become a luscious mouth with red lips and bright white teeth, calling to the hero to "come to Nicky". When people ask me for a quick answer to the question "what do pictures want?" I always tell them they want to be kissed. But then you have to ask yourself: what is a kiss? And the answer to that is that it is a gesture of incorporation, of wanting to swallow up the other without killing them - to "eat them alive" as it were. So we want to take images into our bodies, and they want to take us into theirs. It's a mutual love affair, but one filled with danger and violence and aggression as well as affection.

In your book What do pictures want?, you present a Byzantine picture of Christ whose face has been disfigured to near oblivion by constant kissing. This icon, you write, "is an image that wants the beholder's body and blood and spirit". But, considering the result of the fulfilling of the desires you mention, could we not say that the picture was "addicted"? 0r, viewing the matter from other perspective, isn't it possible that the picture did not want the kisses so much as they were inflicted to it? That is, could we not consider that the image was abused by its beholders? In that case, we would have to deal with the difficult question of how the desires of pictures and humans relate to one another. I do not think the image was abused in this case, even though it was destroyed. The whole liturgical and ritual framework of this process is one of sacrifice, not of abuse. The icon offers its "body" up to the beholder in an exact analogy to the offering of Christ's body and blood in the sacrifice of the Mass, a ritual meal that looks very much like cannibalism, or anthropophagy - what we might think of as the carnal and literal analogue to iconophagy. Of course it could be seen as a form of abuse and even mutilation by someone outside the ritual - by an art historian, for instance, who wants to preserve the icon from destruction. For those within the ritual, however, the kisses are addictive on both sides - both the worshippers' desire and the icons' demand.

This diagram you present in your book Iconology is very enlightening as is the whole chapter "What is an image?" that contains it. Could you comment a little on the myriad of meanings of the term "image"? To use your own question, "what is an image"? 


\section{Image}

likeness

resemblance

similitude

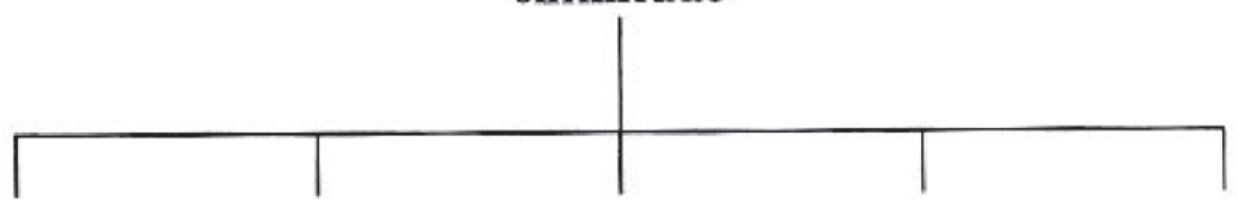

\begin{tabular}{|c|c|c|c|c|}
\hline $\begin{array}{c}\text { Graphic } \\
\text { pictures } \\
\text { starues } \\
\text { designs }\end{array}$ & $\begin{array}{l}\text { Optical } \\
\text { mirrors } \\
\text { projections }\end{array}$ & $\begin{array}{l}\text { Perceptual } \\
\text { sense data } \\
\text { "species" } \\
\text { appearances }\end{array}$ & $\begin{array}{l}\text { Mental } \\
\text { dreams } \\
\text { memories } \\
\text { ideas } \\
\text { fantasmata }\end{array}$ & $\begin{array}{l}\text { Verbal } \\
\text { metaphors } \\
\text { descriptions }\end{array}$ \\
\hline
\end{tabular}

In What do pictures want?, you differentiate between picture and image, treating the first one as a "thing" - an object or a being, a specimen - and the second one as an abstract entity - a species. In Portuguese, we use the word "imagem" for both image and picture, so, here, this very interesting differentiation you propose cannot be drawn from ordinary language. Would you like to say something about that?

I would like to bring your two questions together by modifying the diagram above in a very simple way: draw two ovals, one on the left containing the "Graphic Optical Perceptual" side of the diagram, the other on the right containing the "Perceptual Mental Verbal" side. You will immediately see that they overlap in the center, where the Perceptual is located. Now label the left oval "Pictures" and the right oval "Images" and you will see how the taxonomic diagram of the image is divided between the realm of material pictures - i.e., pictures that can be seen in or on material supports, that can be hung on a wall, printed on a page, or destroyed - and the immaterial pictures that arise in the mind as fantasies, dreams, memories, or the images that arise in a reader's mind as she reads a text, visualizing characters, scenes, and actions, or noticing the striking figures (similes, metaphors) that comprise the domain of verbal images.

Now of course the opposition "material/ immaterial" is just a convenience to help us grasp the picture/image distinction. Both sides are ultimately "material" in the sense that the mental image, for instance, requires the mind-body of the beholder as a material support; and the most solid, material image - a bronze statue - conveys an image that can be copied in another medium, e.g., a photograph, a description, a memory. So the image/picture distinction is not ultimately confined to one side of the family tree of images, but is distributed across them. It is, in my view, part of the fundamental ontology of images that they are BOTH material and immaterial, both embodied in particular objects and places, AND migrating endlessly across the boundaries of bodies and media. Most languages (German, 


\section{PICTURES}

\section{Image}

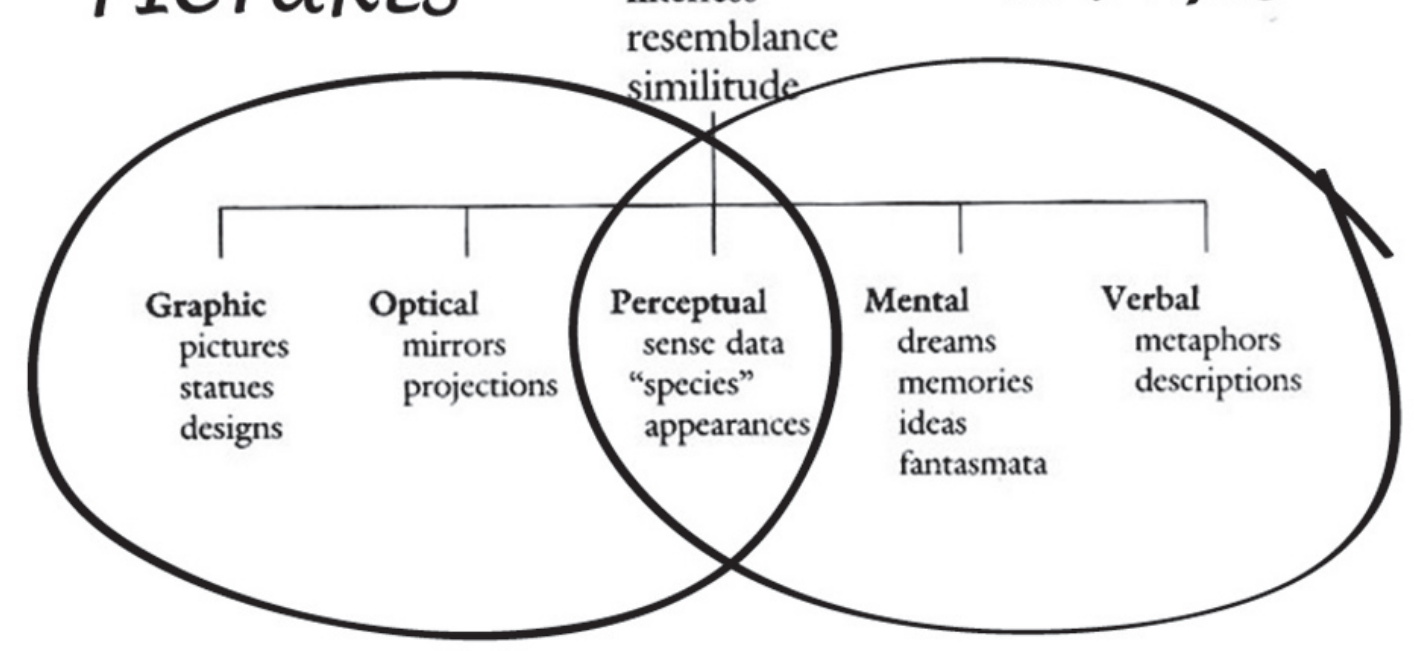

Portuguese) make this seem natural by having, as you point out, just one word (Bild; imagem) for both. English is the only language I know that encourages a vernacular distinction between the image and the picture - the picture is something with a frame that you hang on a wall; the image is something that appears in a picture. Of course, even this vernacular distinction can break down in practice, but it is one that feels natural to a native English speaker.

The overlap between the material and immaterial image is most vividly captured in the overlapping sector of the diagram, the realm of the perceptual image - and, arguably, of the whole CONCEPT of the image that occupies the upper "parent" or "root" position in the tree diagram. The perceptual image is, precisely, "on the border" between material and mental reality. It is the interface between mind and world, an interface that opens, however, into the depths of both the mind and the world.

In your book Iconology, you write that "the history of culture is in part the story of a protracted struggle for dominance between pictorial and linguistic signs, each claiming for itself certain proprietary rights on a 'nature' to which only it has access". This is one of the many points in which, we think, your work approaches the work of Vilém Flusser, a Tcheco-Brazilian philosopher.

Flusser also gives great importance to the struggle you mention. He sees three different moments in this fight. The first is the prehistory in which the image reigns alone. The second - history - starts with the advent of writing and is marked by the struggle between image/imagination and text/conception. When the printing press is invented, the text begins to dominate the image, leading to textolatry. But when textolatry reaches its peak, a third actor - the technical image - comes into play, inaugurating a third moment - post-history. For Flusser, there is a radical difference between image and technical image: the first imagines the world, while the second imagines texts (scientific texts that program the apparatus) that "conceive" images that "imagine" the world. 
Well, it is certainly hard and improper to sum up the complex thought of Flusser here in few lines. Are you acquainted with his work? If you are, what are your impressions of it? Do you think this struggle between text and image can be divided in moments akin to those proposed by Flusser?

I know Flusser's work only slightly, but what

I have read strikes me as very intriguing.

His three-phase history of the word-image struggle reminds me of several other media theorists, notably Marshall McLuhan's fourstage progression from the era of orality to manuscript culture to print culture to the electronic age, or Regis Debray's procession of "mediascapes". I have to admit that I am a bit skeptical about these grand reductions of human history to such a schematic narrative. For one thing, they can lead to a kind of topdown deductive form of historicism, in which once one has defined the essential nature of the era or period, it is all too easy to arrive at a formula for what must be true of all the images, texts, and works of art in that period.

My method emphasizes historical particularity of time and place on the one hand, and on the other, attempts to describe the underlying ontological and phenomenological characteristics of words and images that seem to endure throughout history, thus making it possible for us to make at least partial sense of things (like the Lascaux cave paintings) that are unimaginably distant from us. When it comes to history, then, I want to emphasize anachronism, the tendency of human artifices to leap out of their "period" into ours or someone else's, and to show us how "the time is out of joint". I love the phenomenon of the artist whose work just does not fit the "period style" or dominant mode, but is either regressive or future-oriented, sometimes at the same time (for a great example of this, see Georges DidiHuberman's recent work on Fra Angelico). And I like to read the history of images backwards, as it were, which is my method in Iconology (1987), where I move back from modern theorists such as Nelson Goodman and Ernst Gombrich to comparable figures in the Enlightenment, Lessing and Burke. Or in a more recent paper on the representation of idolatry, I read backwards from Nietzsche to William Blake to Poussin, so that we may look at Poussin's paintings on the theme of idolatry (The Golden Calf and The Plague at Ashdod) with eyes that have been conditioned by the later thinkers.

There is still much discussion about the notion of "society of the spectacle" taking place in the field of Media Studies. As you acknowledge in What do pictures want?, Debord's position could be seen as very iconoclastic and displaying a discomfort with the image that can be felt - again, as you acknowledge - in a vast range of disciplines in our era. This discomfort, it seems, is what led you to coin the phrase "pictorial turn". Could you comment a little about the pictorial turn and about Debord's notion of a "society of spectacle"? I think Debord provided a crucial intervention in the critique of the image, but I doubt its adequacy to our moment now. The iconoclasm is too Manichean and too locked into a hatred of mass culture and mass media as mere instruments of capital. I think we are now in a new media regime that is offering different psychological and social experiences, most 
dramatically, the arise of what Lev Manovich calls "social media" (YouTube, the internet more generally) that make new social movements possible. Obama's election is in part a product of this revolution. If you want my more fully developed critique of Debord as a guide to criticism in our time, you might look at my essay "The Spectacle Today" (2008b).

You have probably answered similar questions a hundred times from now, but we would like very much to hear some iconological thoughts related to the election of Barack Obama.

Obama is not only the first Black president, but the first wired president. He understands, as rarely before in American politics, that political power can be mobilized out of social networks and movements. He also has an unerring grasp of the importance of his own image - that is, his physical, bodily image, and the numerous cultural codes that surround it. To say that he is Black is clearly not enough. He is a mulatto, a hybrid, mestizo, and mixed in every way. He would make a perfect president for Brazil, obviously! In fact, he would make a great leader for any modern democracy that is trying to overcome its dark history of slavery, civil war, and racism. It is no accident that he is a global icon of hope and change, and that this fact was captured graphically by numerous artists, most notably Shepard Fairey, whose posters of Obama will no doubt one day be on U.S. postage stamps.

But aside from the uncanny timeliness of his image, there is Obama's own self-understanding of his role as an icon. He has reflected on this fact very brilliantly, noting that his image makes him an object for the projected hopes of vast multitudes of people. Instead of exploiting this fact, his tendency is to mirror those hopes back on to the multitude, by insisting that "it's not about me. It's about you. We are the one we have been waiting for".

\section{Referências}

BAITELLO JUNIOR, Norval. A era da iconofagia: ensaios de comunicação e cultura. São Paulo: Hacker, 2005.

\section{CRISE DA IMAGEM OU CRISE DAS TEORIAS?}

Simpósio internacional. 2008, São Paulo.

FLUSSER, Vilém. Filosofia da caixa-preta: ensaios para uma futura filosofia da fotografia. Rio de Janeiro: Relume Dumará, 2002 [1983].

MITCHELL, W. J. T. Four fundamental concepts of image science. In: ELKINS, J. (ed.). Visual Literacy. New York: Routledge, 2008a. p. 11-30.

The spectacle today. Public culture, Durham, v.20, n.03, p. 573-581, 2008b.

What do pictures want?: the lives and loves of images. Chicago: University Of Chicago Press, 2005.

Migrating images: totemism, fetishism, idolatry. In: STEGMANN, P. ; SEEL, P. (eds.). Migrating images. Berlin: House of World Cultures, 2004. p. 14-24.

Picture theory. Chicago: The University of Chicago Press, 1994.

Iconology: image, text, ideology. Chicago: The University of Chicago press, 1987 [1986]. 


\section{Expediente}

A revista E-Compós é a publicação científica em formato eletrônico da Associação Nacional dos Programas de Pós-Graduação em Comunicação (Compós). Lançada em 2004, tem como principal finalidade difundir a produção acadêmica de pesquisadores da área de Comunicação, inseridos em instituições do Brasil e do exterior.
E-COMPÓS I www.e-compos.org.br I E-ISSN 1808-2599

Revista da Associação Nacional dos Programas de Pós-Graduação em Comunicação. Brasília, v.12, n.1, jan./abr. 2009.

A identificação das edições, a partir de 2008 passa a ser volume anual com três números.

\section{CONSELHO EDITORIAL}

\section{Afonso Albuquerque}

Universidade Federal Fluminense, Brasil

Alberto Carlos Augusto Klein

Universidade Estadual de Londrina, Brasi

Alex Fernando Teixeira Primo

Universidade Federal do Rio Grande do Sul, Brasil

\section{Alfredo Vizeu}

Universidade Federal de Pernambuco, Brasil

Ana Carolina Damboriarena Escosteguy

Pontifícia Universidade Católica do Rio Grande do Sul, Bras

Ana Silvia Lopes Davi Médola

Universidade Estadual Paulista, Brasil

André Luiz Martins Lemos

Universidade Federal da Bahia, Brasil

Ângela Freire Prysthon

Universidade Federal de Pernambuco, Brasil

Antônio Fausto Neto

Universidade do Vale do Rio dos Sinos, Brasil

Antonio Carlos Hohlfeldt

Pontifícia Universidade Católica do Rio Grande do Sul, Brasil

Arlindo Ribeiro Machado

Universidade de São Paulo, Brasil

César Geraldo Guimarães

Universidade Federal de Minas Gerais, Brasil

Cristiane Freitas Gutfreind

Pontifícia Universidade Católica do Rio Grande do Sul, Brasil

Denilson Lopes

Universidade Federal do Rio de Janeiro, Brasil

Eduardo Peñuela Cañizal

Universidade Paulista, Brasi

Erick Felinto de Oliveira

Universidade do Estado do Rio de Janeiro, Brasil

Francisco Menezes Martins

Universidade Tuiuti do Paraná, Brasil

Gelson Santana

Universidade Anhembi/Morumbi, Brasi

Hector Ospina

Universidad de Manizales, Colômbia

leda Tucherman

Universidade Federal do Rio de Janeiro, Brasil

Itania Maria Mota Gomes

Universidade Federal da Bahia, Brasil

Janice Caiafa

Universidade Federal do Rio de Janeiro, Brasil

Jeder Silveira Janotti Junior

Universidade Federal da Bahia, Brasil

\section{João Freire Filho}

Universidade Federal do Rio de Janeiro, Brasil

John DH Downing

University of Texas at Austin, Estados Unidos

José Luiz Aidar Prado

Pontifícia Universidade Católica de São Paulo, Brasil

José Luiz Warren Jardim Gomes Braga

Universidade do Vale do Rio dos Sinos, Brasil

Juremir Machado da Silva

Pontifícia Universidade Católica do Rio Grande do Sul, Brasil

Lorraine Leu

University of Bristol, Grã-Bretanha

Luiz Claudio Martino

Universidade de Brasília, Brasil

Maria Immacolata Vassallo de Lopes

Universidade de São Paulo, Brasil

Maria Lucia Santaella

Pontifícia Universidade Católica de São Paulo, Brasil

Mauro Pereira Porto

Tulane University, Estados Unidos

Muniz Sodre de Araujo Cabral

Universidade Federal do Rio de Janeiro, Brasil

Nilda Aparecida Jacks

Universidade Federal do Rio Grande do Sul, Brasil

Paulo Roberto Gibaldi Vaz

Universidade Federal do Rio de Janeiro, Brasil

Renato Cordeiro Gomes

Pontifícia Universidade Católica do Rio de Janeiro, Brasil

Ronaldo George Hela

Universidade do Estado do Rio de Janeiro, Brasil

Rosana de Lima Soares

Universidade de São Paulo, Brasil

Rossana Reguillo

Instituto Tecnológico y de Estudios Superiores do Occidente, México

Rousiley Celi Moreira Maia

Universidade Federal de Minas Gerais, Brasil

Sebastião Carlos de Morais Squirra

Universidade Metodista de São Paulo, Brasi

Simone Maria Andrade Pereira de Sá

Universidade Federal Fluminense, Brasil

Suzete Venturelli

Universidade de Brasília, Brasil

Valério Cruz Brittos

Universidade do Vale do Rio dos Sinos, Brasil

Veneza Mayora Ronsini

Universidade Federal de Santa Maria, Brasil

Vera Regina Veiga França

Universidade Federal de Minas Gerais, Brasil
COMISSÃO EDITORIAL

Ana Gruszynski I Universidade Federal do Rio Grande do Sul, Brasil

Rose Melo Rocha I Escola Superior de Propaganda e Marketing, Brasil

CONSULTORES AD HOC

Alberto Schneider I Visitante Tokyo University

Alexandre Rocha da Silva I Universidade Federal do Rio Grande do Sul, Brasil

Fernanda Bruno I Universidade Federal do Rio de Janeiro, Brasil

Ida Stumpf I Universidade Federal do Rio Grande do Sul, Brasil

Kati Caetano I Universidade Tuiuti do Paraná, Brasil

Laura Cánepa I Universidade Anhembi Morumbi, Brasi

Malena Contrera I Universidade Paulista, Brasil

Sandra Gonçalves I Universidade Federal do Rio Grande do Sul, Brasil

Vicente Gosciola I Universidade Anhembi Morumbi, Brasil

REVISÃO DE TEXTO E TRADUÇÃO I Everton Cardoso

EDITORAÇ̃̃o ELETRÔNICA I Raquel Castedo
COMPós I www.compos.org.br

Associação Nacional dos Programas de Pós-Graduação em Comunicação

Presidente

Erick Felinto de Oliveira

Universidade do Estado do Rio de Janeiro, Brasil erickfelinto@uol.com.br

Vice-presidente

Ana Silvia Lopes Davi Médola

Universidade Estadual Paulista, Brasil

asilvia@faac.unesp.br

Secretária-Geral

Denize Correa Araújo

Universidade Tuiuti do Paraná, Brasil

denizearaujo@hotmail.com 